\title{
On the Use of Literary Texts in the DaF Lesson with the Example of Heinrich Boell's Short Story "Die Blasse Anna" with a Focus on Writing on a B2 Level
}

\author{
Yassamin Ostad A. Ghorabi ${ }^{1} \&$ Mohammad Hossein Haddadi ${ }^{1}$ \\ ${ }^{1}$ Faculty for foreign languages and literatures, University of Tehran, Tehran, Iran \\ Correspondence: Yassamin Ostad A. Ghorabi, Faculty for foreign languages and literatures, University of \\ Tehran, Tehran, Iran. E-mail: yassamin.ghorabi@gmail.com
}

Received: February 3, 2017

Accepted: March 6, 2017

Online Published: March 20, 2017

doi:10.5539/jel.v6n3p83

URL: http://doi.org/10.5539/jel.v6n3p83

\begin{abstract}
For the promotion and optimization of teaching foreign languages, new methods and strategies are always considered that include literary texts. The aim of the present paper is to provide arguments for the use of literature in the classroom. Learning target areas and selection criteria for the use of literary texts in the classroom are presented. A short story by German author Heinrich Boell named "Die blasse Anna" will be taken as an example to demonstrate the usability of literary texts in language learning.
\end{abstract}

Keywords: German B2-level, DaF lessons, literary texts in DaF, writing skill

\section{Introduction}

Learning foreign languages is becoming increasingly important. Due to the fast-paced rhythm of life, learning a foreign language must be as fast and efficient as possible. Motivation is key when it comes to efficiency in language learning. One way to generate motivation is the interesting design of teaching lessons by including literary texts. These texts have a fascinating structure, and the proper examination of these texts in the classroom can stimulate the creativity and activity of the learners. In addition, literary texts ensure authenticity in the classroom by providing learners the opportunity to identify with the spirit of different cultures and experiences from generations. The conflict situations over generations, which are usually described in these texts, enforce foreign language learners to discuss and express their opinion.

Until the middle of the 20th century, literature was essential in foreign language teaching. Foreign languages have been tought with the aim of understanding literary texts (Dobstadt \& Riedner, 2011, p. 6; Hunfeld \& Neuner, 1993, p. 31). In the course of the twentieth century, the needs of language learners changes, and so did the teaching methods and didactic objectives. With the introduction of the audio-lingual and audio-visual method, literary texts were banished from foreign language teaching (Dobstadt \& Riedner, 2011, p. 6). In the 1970s, literary texts found their way back into foreign language teaching, as dissatisfaction with the focus of foreign language teaching and the provision of teaching material prevailed (Ehlers, 2010, p. 1530). In the 1980s, Hunfeld drew up the model of "hermeneutic literary teaching" (Koppensteiner \& Schwarz, 2012, p. 26), which sees literature as "open, reality-related, natural, but not arbitrary given speaking-occasions" (Hellweg, 2005, p. 57; In: Koppensteiner \& Schwarz, 2012, p. 26). In 1985, Weinreich recommended the use of literary texts in the DaF classes. He argued that literary texts can arouse the interest of the learners in the classroom, because of their aesthetic quality (Dobstadt \& Riedner, 2011, p. 6). Kast also recommened the use of these texts in foreign language teaching and introduced the concepts of intercultural and action-oriented literature teaching (Kast, 1999) (ibid.). In today's widely spread concept of communicative foreign language teaching, literary texts are usually used as supplementary material to stimulate speech production. In the textbooks, however, these texts have hardly been accepted (ibid.).

Not much attention have been given to the advantages of including literary texts in language learning resulting in the almost banishment of these texts from the curricula. This article deals with the advantages of literary texts and their positive impact on learners. Furthermore, learning objectives and selection criteria are examined for the correct choice of texts for the DaF instruction. Finally, a lesson is shown, which uses a short story at B2 level in order to focus on the training of the writing skill. 


\section{Methods}

This work deals first with a literature review and calls theories to work with literary texts. Then an instructional sketch is given to work with a short history, which was used in a German course at an Iranian language institute. Learners were asked about their opinion on working with the short story. Finally the answers to the survey are given.

\subsection{Arguments for the Use of Literary Texts in Foreign Language Teaching}

"The literature of a nation is like a window from which this people see the stranger, through whom the stranger can gain insight into the life of this people" (Dedecius, 1974, p. 81).

The examination of literature is also an examination of art. This area of art is highly valued in every society. For many, the reading of literary texts is an important part of their everyday life. This part of life is a means of communicating with friends or can serve as a means of contacting new people. Therefore, literature can have a "community-promoting and even a community-building impact" (Leubner et al., 2016, p. 29).

In antiquity, the Roman poet Horace assigned the functions "use" and "delight" to literature. One reading of these attributes is that literary texts are supposed to "teach (moral) lessons or knowledge in an entertaining or aesthetically pleasing package"” (ibid.).

Further, literature supporting arguments in this respect speak on the content level of literary texts being interesting, and induce in no way boredom. Correctly selected texts, which correspond to the language level of the learners, can offer tension and concern and thus arouse interest and commitment (Herrmann, 1984, p. 24; In: Koppensteiner \& Schwarz, 2012, p. 30).

Literary texts are to be seen as the antithesis of the simulated and artificially created dialogues of textbooks, which can ensure authenticity in class, as they are "identification offers for young people, distance aids, escape possibilities, and also offer cheerfulness but also death and grief" (Butzkamm, 1985, p. 92; Ibid.). They can also be seen as life aids. Literary texts offer experiences that can play a major and important role in the personal development of the reader and their interaction with society (Leubner et al., 2016, p. 30).

The composition of literary texts seduces readers to read more and create interest and a sense of fascination. Because of described conflict situations, discussion possibilities arise in the classroom.

On a linguistic level, Haeussermann argues that literary texts-in contrast to popular, semi-literary and particularly newspaper texts - reproduce the "better German". The correct selection of literary texts can support the learning of languages, because the texts are well-structured, the words have been carefully chosen and they are particularly distinctive (1984, p. 31; In: Koppensteiner \& Schwarz, 2012, p. 30).

This reasoning can be added to the fact that the vocabulary of literary texts contain words of "thinking and feeling", which are scarcely found in textbooks, and therefore should be seen as "a welcome addition to the vocabulary learned so far" (Bieler \& Jenkins, 1991, p. 8). The beauty of literary language prevents language learners from communicating with the real world only on the level of textbooks.

On the didactic-methodological level, literary texts can offer a communicative-oriented lesson, provided that "the literature is demystified and reservations are relieved" (Koppensteiner \& Schwarz, 2012, p. 31). The strong stimulus potential of literary texts offers possibilities of linguistic response for both, consent or rejection. Furthermore, literary texts are more memorable than other texts. Linguistic structures can thus be better absorbed and noted. Through the use of literary texts in language teaching, the triviality of textbook texts can be countered and artificial communication possibilities can be transformed into real everyday communication.

In addition, literary texts are an "essential part of the target-minded spiritual world, and thus also of the country tradition" (Bieler \& Jenkins, 1991, p. 6; In: ebd., p. 32). Literary texts contain different world aspects and perspectives on the world and thus offer the possibility to extend the "perception and knowledge horizon" (Ehlers, 2001, p. 1335) to relativize one's own perspective and learn and understand more from the target language culture and its members (Ibid.). In one of his articles, Harald Weinreich argues that "to teach a cultural language as a foreign language without teaching their literature at the same time is a form of barbarism" (1984, p. 11; In: Koppensteiner, 2001, p. 17). In his opinion the complexity of the literature should not be avoided because it is precisely the complexity that prepares for the everyday life, the complexity of life can not be avoided.

\subsection{Learning Target Areas}

According to Kast, literary texts in teaching a foreign language pursue a specific goal: in "Foreign-language-literature, the foreign literature, in foreign-language-literature, the language to be learned 
and in foreign-language-literature, the literature of this foreigner and of this language" (1985, p. 28; In: ibid., p. 49). This means that including litrature in language teaching can cover many important and necessary areas of foreign language learning, i.e., the linguistic level, which includes grammar and vocabulary and the cultural level that focuses on the unknown of the new culture.

Among other things, attitude formation, language acquisition, teaching of language and literature can be mentioned as a target for the use of literary texts in foreign language teaching (Koppensteiner/Schwarz 2012: 44ff.). They are described in more detail below.

\subsubsection{Attitude Formation}

Literary texts present the traditions, the attitudes of the people of a society, the prevailing values and many other social and cultural aspects of a society. The intensive examination of literary texts is, at the same time, an examination of the mentioned characteristics of such texts. This dispute affects the reader's attitude towards the presented society. The selected texts for this purpose are intended to correspond to the interest of the readers in order to influence them while ensuring a critical distance (ibid., 44f.).

\subsubsection{Language Acquisition}

The integration of literary texts in the DaF classroom entails the intensive study of language. This requires the four skills of speaking, listening, reading and writing. They can all be trained very well in dealing with these texts.

Reading skill plays a central role in the reading of literary texts. The aim of the foreign language readers to read a text is to "(largely) independently meet their needs for information contained in a foreign language text" (Westhoff, 1997, p. 7). For this purpose, reading strategies, structural features and the function and application of structural markers have to be mediated (Ehlers, 1992, p. 14).

The reading of texts, especially authentic ones, leads to a better understanding of the combination of letters in the language and thus to the faster identification of words and the recognition of logical sentence structures. This will consequently lead to faster reading and understanding (Westhoff, 1997, p. 59).

Speaking skills are trained through communicative activities when discussing a text, expressing the own opinion on the text, addressing issues of uncertainty in a text or asking questions. If a text is to be discussed in the literary lesson, it is important and necessary to provide the required discourses and to practice them with the learners (Schatz, 2006, p. 19). Presentations on literary texts are also a means of training the speaking skill.

Hearing skills can be trained through the use of listening-texts, such as radio plays, listening scenes or songs. With various tasks, different listening styles can be trained, e.g., global, selective or detailed styles.

In writing, the processes slow down compared to speaking. While in speaking the order of thoughts must take place very quickly (and thus content and linguistic problems can arise), in writing, the thoughts can be arranged and time for further reflection is won (Kast, 1999, p. 23). With regard to literary teaching of foreign languages, thoughts about the literary texts that have been worked on in the class, can be written down. Those written textes can be for example, interpretations, the thoughts of the actors in the text, text summaries, letters, and much more.

\subsubsection{Literature and Grammar and the Promotion of Language Awareness}

"In addition to literary, social, and mediality, the linguistic nature of the literary text is a fourth aspect in the classroom" (Klotz, 1997, 226ff., In: Abraham \& Kepser, 2009, p. 139). The linguistic nature of the literary text includes the "lexical and grammatical signs, belongings to a texttype, style and register, means of cohesion and the distribution of rhetorical means" (ibid., p. 230). By dealing with literary texts, distance is taken to one's own linguistic usage, the reader is sensitized to "nuances in the context of (language) aesthetic education" (Hohm, 2008; In ibid., p. 140). Learners are thus sensitized to the active use of the language.

\subsubsection{Literature and Regional Studies}

If the definiton of the concept of "regional studies" is not limited to facts of the target culture -such as the number of inhabitants- but also includes values, belief, concepts of space and time, and attitudes (Bishof, 1999, p. 7), it will lead to an understanding of the relationship between literature and regional studies. Such texts, for example nonfiction texts, can report on the history and society, the behaviors and other cultural-specific characteristics of the target culture (ibid.).

The peculiarity of literary texts is that they contain "something general" in specific experience situations and individual destinies (ibid., p. 12), which transcends cultural boundaries and offers a basis of understanding. 
This definiton of regional studies has an educational benefit because the reader is integrated in the culture by establishing cultural norms and values (Leubner et al., 2016, p. 30).

The openness of literary texts offers readers the opportunity to analyze and interpret the described situation against the background of their own experiences. This makes a comparison of two cultures possible, whereby differences or similarities between the two cultures become visible. The resulting new view of one's own world can lead to a change in behavior and basic attitudes in readers and thus evoke a further development of one's own culture (ibid., p. 34). Teaching should provide the opportunity to address these differences and similarities so that stereotypes can be avoided and overcomed.

\subsection{Selection Criteria of Literary Texts}

The selection of literary texts for foreign language teaching is subject to several criteria:

\subsubsection{Textuality}

The question which topic is actually up-to-date is variable in different countries. Herrmann's opinion is that texts from "non-committal time and history" can be transferred to the present and thus into everyday life of the learners. This can cause resonance (Herrmann, 1984, p. 22; In: Koppensteiner, 2001, p. 43). Such texts are always up-to-date and can always be used in teaching.

\subsubsection{Age and Linguistic Adequacy}

The selected literature for foreign language teaching must be age-related and reflect the world-knowledge and the experiences of the learners. The proximity of the text to world-knowledge and the experiences of the readers can facilitate the understanding of the text.

The substantive adequacy is also a very important criterion. In a sense, this criterion is related to the criterion of timeliness. Themes that are up-to-date in a country can be seen in some other country as old and overtaken. Editing such topics would only cause perplexity and disinterest among readers, because there is no frame of reference.

The texts presented must also correspond to the reader's level of speech. It has to start with linguistically simple texts and gradually increase the speech level. The reading text should have a level of simplicity to ensure that learners understand the content after the first read to a large extent. By doing so, it will be ensured that in a secons read, more attention is payed to details (Mummert, 1987, p. 51; In Heyd, 1997, p. 125). The chosen text should be easy to read in terms of language but also content and appeal to readers' intellect and emotions (see Hunfeld, 1990, p. 99).

\subsubsection{Varieties of Language}

The German language area consists of three countries, which bring their own culture and their own variant of the German language: Germany, Austria and Switzerland. However, they also have a lot of cultural interests in common, and because of these similarities, these countries are referred to as "cultur-nation" (see Koppensteiner, 2001, p. 44). Language culture is the most important common feature of these countries, with all the variations, the diversity and the characteristics that it offers. This language culture includes Duerrenmatt and Frisch, Bernhard and Zweig, just like Mann and Boell.

\subsubsection{Intercultural Perspective}

Foreign language teaching is also an intercultural education. Cultural elements and norms of the target-language-country are compared with those of their own culture. This leads to an intercultural discussion with a particular topic. According to Nuenning, texts for foreign language literary teaching should be selected in which the "external comprehension or intercultural misunderstanding" (2000, p. 113, in Koppensteiner, 2012, p. 55) play a central role. Also texts "which place the process of external comprehension themselves into the center" (ibid., p. 115, in ibid.) are suitable. This is also true for "multiperspectively narrated novels, in which understanding the foreign language not only presents and/or thematizes at the level of the figures, but is also formally staged at the level of narrative mediation" (ibid.).

\subsection{Instructional Sketch for the Use of the Short Story, "Die Blasse Anna” by Heinrich Böll (B2 level)}

In this part, an example lesson by using Heinrich Boell's short story "Die blasse Anna" is given. The story takes place in the aftermath of the Second World War and shows life conditions in Germany at that time. Since this is an important part of Germanys history, it is important for learners to know about, so that they can learn more about Germanys culture (see. 2.2.4 Literature and regional studies). 
The issue of war and the time thereafter is currently actual in many countries: the current wars in the Middle East and the related refugee waves are same examples to name. The actuality of this topic could provide many language learners, whether or not affected by this topic, with a comparative basis between the culture of German-speaking countries and their own culture in dealing with this situation (see 2.3.1 Textuality). After reading this text learners can discuss the topic of war and the time after and compare it to the same situation in their own country or in the neighboring countries (see 2.3.4 Intercultural perspective).

First phase: Activate or build up prior knowledge

A. The plot of this short story is in the postwar period of World War II.

The teacher writes the word "postwar period" in the form of an associogram on the board. The students have to complement it with all the words that come to them. They can report their own experiences, or reproduce read or heard information.

B. Participants will be informed about the circumstances of the Second World War in Germany (for example, money shortages, few living quarters, cohabitation of several strangers in a house etc.)

C. In order to prepare language learners for the reading of the text and to build up tension, groups with participants of 3-4 are formed. They are given sentences from the short story and have to write a story by their own and present it in the plenum.

The following sentences can be given:

Erst im Frühjahr 1950 kehrte ich aus dem Krieg heim, und ich fand niemanden mehr in der Stadt, den ich kannte. (I came back home from war in spring 1950. There was no one in town anymore that I would know.)

Arbeiten zu gehen, hatte ich keine Lust.

(I did not feel like going to work.)

Ihr Sohn war in einem Ort gefallen, der Kalinowka hieß.

(Her son was fallen in a place called Kalinowka.)

Jedesmal blickte ich sehr lange auf das Foto, das den Sohn meiner Wirtin an der Endstation der 9 zeigte, und ich dachte an vieles: an das Mädchen und an die Seifenfabrik, in der ich damals gearbeitet hatte...

(I always used to look at the picture for a long time; it showed the son of my landlord at the terminal stop of line 9. The picture made me think of many things: of the girl in the soup factory I used to work in...)

Manchmal hörte ich im Zimmer nebenan die Schritte eines Mädchens. Sie wurde vom Luftdruck in ein Schaufenster geschleudert.

(Sometimes I heard steps of a girl in the room next door. She was thrown through a shop window by the pressure of the air.)

Ich legte meine Hand auf Annas Schulter und versuchte zu lächeln.

(I put my hand on Anna's shoulders and tried to smile.)

In such exercises the writing skill and the creativity of the learners are encouraged. The most important aspect is that the learners are motivated by such exercises and become active in the classroom.

Second phase: Beginning in the text work/text understanding

Once the text has been read, the second phase begins. Since after the first reading, foreign language learners are still busy with understanding specific incidents, no open questions can be asked at this stage. There should be specific questions about the text being read in order to secure the global text understanding. The following task is performed:

A. The learner will be asked to review the short story again and add the following sentences in pair work and compare it in the plenum:

Die Geschichte handelt von ... (The story is about...)

Die Geschichte spielt in ... (The story takes place in...)

Die Geschichte spielt in der Zeit ... (The story takes place in the time of...)

Die Hauptpersonen sind ... (The main characters are...)

Am Ende ... (At the end...) 
B. The participants analyze the characters by writing a profile with the following information on the main characters of the story (the narrator, Anna, the housekeeper):

Name, age, origin, occupation, family status, appearance, characteristics and other

Third phase: Retelling the specific event

After securing the global understanding of the text, it now comes to grasping the specific event and then to recount the action.

A. Learners write 10-15 words out of the readed text in pair work, which in their opinion are important for the tale of this short story. This list will be exchanged among the learners so that each pair has a new word list in front of them.

B. With the words of the new word list, each pair of learners writes a renarration.

C. The participants are divided into groups of 3-4 persons each. Depending on the number of groups, the teacher seeks some re-enumerations which they distribute among the groups, each group should have a re-enumeration. Now the groups have to reduce the present recount to half, so that only important information remains in the re-enumeration.

Fourth phase: Deepening the understanding of the text/reader expectations

This phase is devoted to the interpretation of the learner. For this reason, questions of interpretation and questions about the open texts of the learner are put up for discussion.

A. Learners write their questions, which are then discussed in small groups of 3-4 persons, or in plenary sessions. The results are then summarized and recorded in the plenum.

B. The following question is discussed or answered in pair work or in small groups, which are finally discussed in the plenum:

What would have happened if the narrator had not looked closely at the photo and had not recognized Anna?

C. The teacher points out the characteristics of the short stories in the table (see Table 1.) and asks the participants to examine and mark the text on these characteristics. Subsequently, the answers in the plenum are discussed and checked.

Table 1. Characteristics of the short story

\begin{tabular}{lll}
\hline abrupt beginnig & colloquial language & important and special situation \\
\hline open end & Figuers are important personalities & normal and commen situation \\
\hline clear end & Figuers are normal people & neutral point of view \\
\hline
\end{tabular}

\section{Fifth phase: Productive phase}

In the final phase, the learner should work productively. The following task is performed:

A. Write the short story from the perspective of the housekeeper or Anna again. Observe the characteristics of the short story, such as an abrupt entry, open end, the everyday language, etc.

This task is worked out in pair work and finally presented in the plenum. The texts can be enlarged and hung up in the classroom. In this way, the learners are motivated to be productive in class.

The last task to be addressed is the following:

B. What do you think the narrator and Anna will say to each other in their first meeting? Please write the dialogue between Anna and the narrator. Play the dialogue in plenary.

\subsection{Survey}

After working with this short story, the learners were asked about their opinion on working with creative texts. The following sentences were given.

1) I enjoy writing creative texts.

2) I am not afraid to write creative texts in German.

3) I can better combine my thoughts and sentences and write a more comprehensible text. 
Learners had to choose among the following categories:

$1 \rightarrow$ Completely agree

$2 \rightarrow$ Agree

$3 \rightarrow$ Partially agree

$4 \rightarrow$ hardly meets

$5 \rightarrow$ do not agree

\section{Results}

The following graphs show the evaluation of the questions.

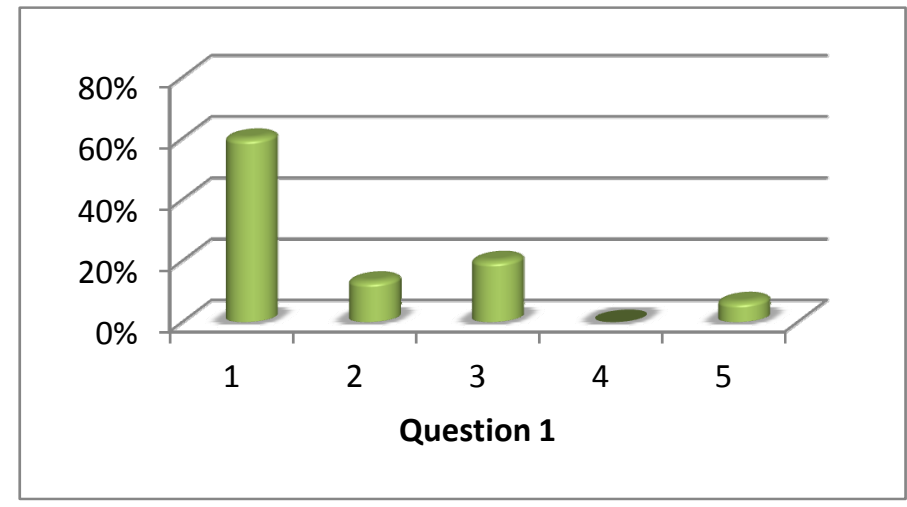

Figure 1. Graph to the evaltuation of Question 1: I enjoy writing creative texts

More than $70 \%$ of the learners enjoyed writing creative texts. $60 \%$ of them agreed fully with the statement above, $13 \%$ partially agreed. Only $7 \%$ did not agree.

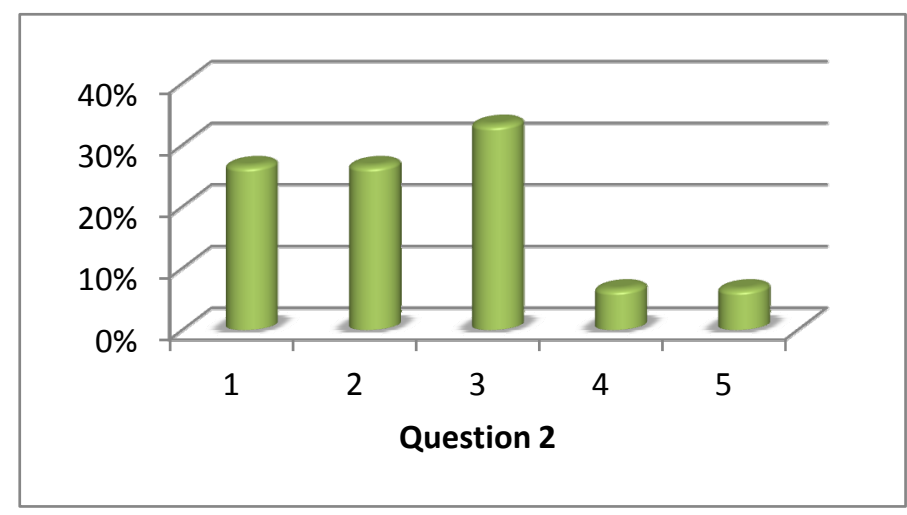

Figure 2. Graph to the evaltuation of Question 2: I am not afraid to write creative texts in German

Over half of the asked learners are no longer afraid to write creative texts in German. 33\% of the respondents agreed partially with the statement above-mentioned. 


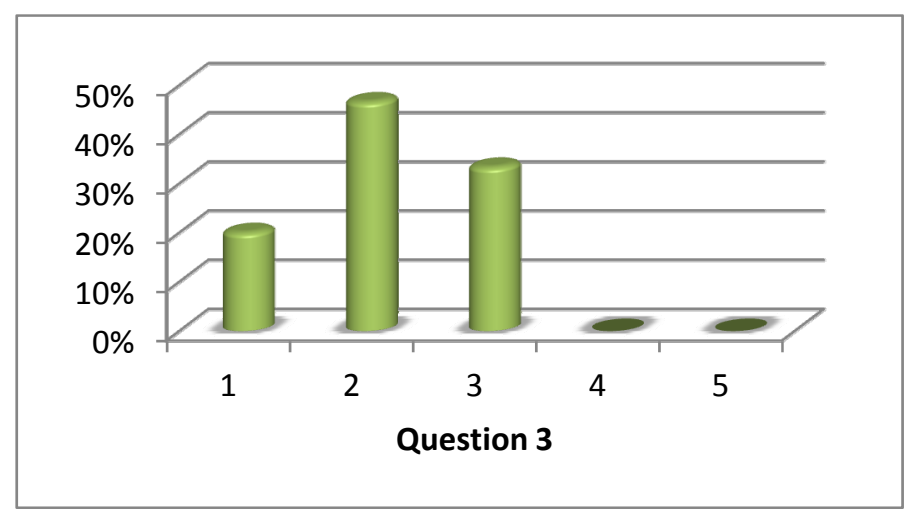

Figure 3. Graph to the evaltuation of Question 3: I can better combine my thoughts and sentences and write a more comprehensible text

$20 \%$ of the learners completely agreed, that they can combine their thoughts and sentences better and write a more comprehensible text. $47 \%$ also agreed.

The short story was simply structured and clearly understood. This corelated to the selection criteria mentioned above. This short story deals with the issues of war and the time after it. Therefore it was felt by many, as there are many wars around Iran today, and the learners are confronted with this issue every day. The short story also brought the learners closer to the culture and behavior of the Germans at this time. This is also a criterion for the correct selection of texts, as described above. The steps to approach the text, which I developed, made it easier for the learners to work with the text.

The evaluation of the survey shows that the learners have produced texts with pleasure and have further developed their writing skills. They feel more self-assured when writing texts (see question 3).

\section{Conclusion}

The theoretical part of this paper has subjected Heinrich Boell's short story to a critical analysis against the backdrop of the use of literary texts in the $\mathrm{DaF}$ lesson. It shows that correctly selected texts that correspond to the language level of the learner (here at the B2 level) facilitate their language learning and rises motivation. The interest in learning and the curiosity of the learners is aroused in the culture of the country whose language is learned. The survey also showed that using literary texts can aprove the writing skill of learners and also vitalise the learning class. Literary texts, in particular up-to-date and authentic ones, must find a firm place in the curricula and constitute an essential part in the DaF-teaching.

\section{References}

Abraham, U., \& Kepser, M. (2009). Literaturdidaktik Deutsch-Eine Einführung. Erich Schmidt Verlag. Berlin, Germany.

Bischof, M. et al. (1999). Landeskunde und Literaturdidaktik. Langenscheidt, Muenchen, Germany.

Böll, H. (1992). Die blasse Anna. In: Nicht nur zur Weihnachtszeit. Erzählungen, Deutscher Taschenbuchverlag, Muenchen, Germany.

Dobstadt, M., \& Riedner, R. (2011). Fremdsprache Literatur. Neue Konzepte zur Arbeit mit Literatur im Fremdsprachenunterricht. In Fremdsprache Deutsch 44/2011 (pp. 5-14).

Ehlers, S. (1992). Lesen als Verstehen. Arbeit mit literarischen Texten. Langenscheidt, Muenchen, Germany.

Ehlers, S. (2001). Literatur als Gegenstand des fremdsprachlichen Deutschunterrichts. In G. Helbig et al. (Eds.), Deutsch als Fremdsprache. Ein internationales Handbuch (pp. 1334-1346). de Gruyter Verlag, Berlin,

Ehlers, S. (2010). Literarische Texte im Deutsch las Fremd- und Zweitsprache-Unterricht: Gegenstaende und Ansaetze. In H. J. Krumm et al. (Eds.), Deutsch als Fremd- und Zweitsprache (pp. 1531-1544). Ein internationales Handbuch De Gruyter, Berlin, Germany.

Heyd, G. (1997). Aufbauwissen für den Fremdsprachenunterricht (DaF). Ein Arbeitsbuch. Kognition und Konstruktion. Gunter Narr Verlag, Tuebingen, Germany. 
Hunfeld, H. (1990). Literatur als Fremdsprache. Ansaetze eines hermeneutisch orientierten Fremdsprachenunterrichts. Langenscheidt, Berlin and Muenchen, Germany.

Kast, B. (1999). Fertigkeit Schreiben. Langenscheidt, Muenchen, Germany.

Koppensteiner, J. (2001). Literatur im DaF-Unterricht. Eine Einfuehrung in produktiv-kreative Techniken. Oebv \& hpt Verlags GmbH \& Co. KG, Wien, Austria.

Koppensteiner, J., \& Schwarz, E. (2012). Literatur im DaF/DaZ-Unterricht. Eine Einfuehrung in Theorie und Praxis. Praesens Verlag, Wien, Austria.

Leubner, M. et al. (2016). Literaturdidaktik. Walter de Gruyter GmbH, Berlin, Germany, Boston, USA.

Neuner, G., \& Hunfeld, H. (1993). Methoden des Fremdsprachenunterrichts. Eine Einfuehrung. Langenscheidt, Kassel, Germany.

Schatz, H. (2006). Fertigkeit Sprechen. Langenscheidt, Muenchen, Germany.

Tuetken, G. (2006). Literatur im Unterricht Deutsch als Fremdsprache an der Hochschule im Ausland-aber wie? Ein Vorschlag am Beispiel Russlands. In Info DaF. Informationen Deutsch als Fremdsprache (pp. 52-90).

Westhoff, G. (1997). Fertigkeit Lesen. Langenscheidt, Muenchen, Germany.

\section{Appendix}

\section{Heirich Böll's short story—Die blasse Anna}

Erst im Frühjahr 1950 kehrte ich aus dem Krieg heim, und ich fand niemanden mehr in der Stadt, den ich kannte. Zum Glück hatten meine Eltern mir Geld hinterlassen. Ich mietete ein Zimmer in der Stadt, dort lag ich auf dem Bett, rauchte und wartete und wusste nicht, worauf ich wartete. Arbeiten zu gehen, hatte ich keine Lust. Ich gab meiner Wirtin Geld, und sie kaufte alles für mich und bereitete mir das Essen. Jedesmal, wenn sie mir den Kaffee oder das Essen ins Zimmer brachte, blieb sie länger, als mir lieb war. Ihr Sohn war in einem Ort gefallen, der Kalinowka hieß, und wenn sie eingetreten war, setzte sie das Tablett auf den Tisch und kam in die dämmrige Ecke, wo mein Bett stand. Dort döste ich vor mich hin, drückte die Zigaretten an der Wand aus, und so war die Wand hinter meinem Bett voller schwarzer Flecken. Meine Wirtin war blass und mager, und wenn im Dämmer ihr Gesicht über meinem Bett stehen blieb, hatte ich Angst vor ihr. Zuerst dachte ich, sie sei verrückt, denn ihre Augen waren sehr hell und groß, und immer wieder fragte sie mich nach ihrem Sohn.

"Sind Sie sicher, dass Sie ihn nicht gekannt haben? Der Ort hieß Kalinowka - sind Sie dort nicht gewesen?"

"Aber ich hatte nie von einem Ort gehört, der Kalinowka hieß, und jedesmal drehte ich mich zur Wand und sagte: Nein, wirklich nicht, ich kann mich nicht entsinnen."

Meine Wirtin war nicht verrückt, sie war eine sehr ordentliche Frau, und es tat mir weh, wenn sie mich fragte. Sie fragte mich sehr oft, jeden Tag ein paarmal, und wenn ich zu ihr in die Küche ging, musste ich das Bild ihres Sohnes betrachten, ein Buntphoto, das über dem Sofa hing. Er war ein lachender blonder Junge gewesen, und auf dem Buntphoto trug er eine Infanterie-Ausgehuniform.

"Es ist in der Garnison gemacht worden", sagte meine Wirtin, "bevor sie ausrückten." Es war ein Brustbild: er trug den Stahlhelm, und hinter ihm war deutlich die Attrappe einer Schloßruine zu sehen, die von künstlichen Reben umrankt war.

"Er war Schaffner", sagte meine Wirtin, "bei der Straßenbahn. Ein fleißiger Junge”. Und dann nahm sie jedesmal den Karton voll Photographien, der auf ihrem Nähtisch zwischen Flicklappen und Garnknäueln stand. Und ich musste sehr viele Bilder ihres Sohnes in die Hand nehmen. Gruppenaufnahmen aus der Schule, wo jedesmal vorne einer mit einer Schiefertafel zwischen den Knien in der Mitte saß, und auf der Schiefertafel stand eine VI, eine VII, zuletzt eine VIII. Gesondert, von einem roten Gummiband zusammengehalten, lagen die Kommunionbilder: ein lächelndes Kind in einem frackartigen schwarzen Anzug, mit einer Riesenkerze in der Hand, so stand er vor einem Transparent, das mit einem goldenen Kelch bemalt war. Dann kamen Bilder, die ihn als Schlosserlehrling vor einer Drehbank zeigten, das Gesicht rußig, die Hände um eine Feile geklammert.

"Das war nichts für ihn", sagte meine Wirtin, "es war zu schwer”. Und sie zeigte mir das letzte Bild von ihm, bevor er Soldat wurde: er stand in der Uniform eines Straßenbahnschaffners neben einem Wagen der Linie 9 an der Endstation, wo die Bahn ums Rondell kurvt, und ich erkannte die Limonadenbude, an der ich so oft Zigaretten gekauft hatte, als noch kein Krieg war; ich erkannte die Pappeln, die heute noch dort stehen, sah die Villa mit den goldenen Löwen vorm Portal, die heute nicht mehr dort stehen, und mir viel das Mädchen ein, an das ich während 
des Krieges oft gedacht hatte: sie war hübsch gewesen, blass, mit schmalen Augen, und an der Endstation der Linie war sie immer in die Bahn gestiegen.

Jedesmal blickte ich sehr lange auf das Photo, das den Sohn meiner Wirtin an der Endstation der 9 zeigte, und ich dachte an vieles: an das Mädchen und an die Seifenfabrik, in der ich damals gearbeitet hatte, ich hörte das Kreischen der Bahn, sah die rote Limonade, die ich im Sommer an der Bude getrunken hatte, grüne Zigarettenplakate und wieder das Mädchen.

"Vielleicht", sagte meine Wirtin, "haben Sie ihn doch gekannt". Ich schüttelte den Kopf und legte das Photo in den Karton zurück: es war ein Glanzphoto und sah noch neu aus, obwohl es schon acht Jahre alt war.

"Nein, nein", sagte ich, "auch Kalinowka, -wirklich nicht".

Ich musste oft zu ihr in die Küche, und sie kam oft in mein Zimmer, und den ganzen Tag dachte ich an das, was ich vergessen wollte: an den Krieg, und ich warf die Asche meiner Zigarette hinters Bett, drückte die Glut an der Wand aus.

Manchmal, wenn ich abends dort lag, hörte ich im Zimmer nebenan die Schritte eines Mädchens, oder ich hörte den Jugoslawen, der im Zimmer neben der Küche wohnte, hörte ihn fluchend den Lichtschalter suchen, bevor er in sein Zimmer ging.

Erst als ich drei Wochen dort wohnte, als ich das Bild von Karl wohl zum fünfzigsten Mal in die Hand genommen, sah ich, dass der Straßenbahnwagen, vor dem er lachend mit seiner Geldtasche stand, nicht leer war. Zum ersten Mal blickte ich aufmerksam auf das Photo und sah, dass ein lächelndes Mädchen im Inneren des Wagens mitgeknipst worden war. Es war die Hübsche, an die ich während des Krieges so oft gedacht hatte. Die Wirtin kam auf mich zu, blickte mir aufmerksam ins Gesicht und sagte: "Nun erkennen Sie ihn, wie?" Dann trat sie hinter mich, blickte über meine Schulter auf das Bild, und aus ihrer zusammengerafften Schürze stieg der Geruch frischer Erbsen an meinem Rücken herauf.

"Nein", sagte ich leise, "aber das Mädchen".

"Das Mädchen?” sagte sie, "das war seine Braut, aber vielleicht ist es gut, dass er sie nicht mehr sah-"

"Warum?" fragte ich.

Sie antwortete mir nicht, ging von mir weg, setzte sich auf ihren Stuhl ans Fenster und hülste weiter.

Erbsen aus. Ohne mich anzusehen, sagte sie: "Kannten Sie das Mädchen?"

Ich hielt das Photo fest in meiner Hand, blickte meine Wirtin an und erzählte ihr von der Seifenfabrik, von der Endstation der 9 und dem hübschen Mädchen, das dort immer eingestiegen war.

"Sonst nichts?"

"Nein", sagte ich, und sie ließ die Erbsen in ein Sieb rollen, drehte den Wasserhahn auf, und ich sah nur ihren schmalen Rücken.

"Wenn Sie sie wiedersehen, werden Sie begreifen, warum es gut ist, dass er sie nicht mehr sah-".

"Wiedersehen?" sagte ich.

Sie trocknete ihre Hände an der Schürze ab, kam auf mich zu und nahm mir vorsichtig das Photo aus der Hand. Ihr Gesicht schien noch schmäler geworden zu sein, ihre Augen sahen an mir vorbei, aber sie legte leise ihre Hand auf meinen linken Arm. "Sie wohnt im Zimmer neben Ihnen, die Anna. Wir sagen immer blasse Anna zu ihr, weil sie so ein weißes Gesicht hat. Haben Sie sie wirklich noch nicht gesehen?"

"Nein", sagte ich, "ich habe sie noch nicht gesehen, wohl ein paarmal gehört. Was ist denn mit ihr?"

"Ich sag's nicht gern, aber es ist besser, Sie wissen es. Ihr Gesicht ist ganz zerstört, voller Narben-sie wurde vom Luftdruck in ein Schaufenster geschleudert. Sie werden sie nicht wiedererkennen". Am Abend wartete ich lange, bis ich Schritte in der Diele hörte, aber beim ersten Male täuschte ich mich: es war der lange Jugoslawe, der mich erstaunt ansah, als ich so plötzlich in die Diele stürzte. Ich sagte verlegen "Guten Abend" und ging in mein Zimmer zurück.

Ich versuchte, mir ihr Gesicht mit Narben vorzustellen, aber es gelang mir nicht, und immer, wenn ich es sah, war es ein schönes Gesicht, auch mit Narben. Ich dachte an die Seifenfabrik, an meine Eltern und an ein anderes Mädchen, mit dem ich damals oft ausgegangen war. Sie hieß Elisabeth, ließ sich aber Mutz nennen, und wenn ich sie küßte, lachte sie immer, und ich kam mir blöde vor. Aus dem Krieg hatte ich ihr Postkarten geschrieben, und 
sie schickte mir Päckchen mit selbstgebackenen Plätzchen, die immer zerbröselt ankamen, sie schickte mir Zigaretten und Zeitungen, und in einem ihrer Briefe stand:

"Ihr werdet schon siegen, und ich bin so stolz, dass du dabei bist". Ich aber war gar nicht stolz, dass ich dabei war, und als ich Urlaub bekam, schrieb ich ihr nichts davon und ging mit der Tochter eines Zigarettenhändlers aus, der in unserem Haus wohnte. Ich gab der Tochter des Zigarettenhändlers Seife, die ich von meiner Firma bekam, und sie gab mir Zigaretten, und wir gingen zusammen ins Kino, gingen tanzen, und einmal, als ihre Eltern weg waren, nahm sie mich mit auf ihr Zimmer, und ich drängte sie im Dunkeln auf die Couch; aber als ich mich über sie beugte, knipste sie das Licht an, lächelte listig zu mir hinauf, und ich sah im grellen Licht den Hitler an der Wand hängen, ein Buntphoto, und rings um den Hitler herum, an der rosenfarbenen Tapete, waren in Form eines Herzens Männer mit harten Gesichtern aufgehängt, Postkarten mit Reißnägeln befestigt, Männer, die Stahlhelme trugen und alle aus der Illustrierten ausgeschnitten waren. Ich ließ das Mädchen auf der Couch liegen, steckte mir eine Zigarette an und ging hinaus. Später schrieben beide Mädchen mir Postkarten in den Krieg, auf denen stand, ich hätte mich schlecht benommen, aber ich antwortete ihnen nicht... Ich wartete lange auf Anna, rauchte viele Zigaretten im Dunkeln, dachte an vieles, und als der Schlüssel ins Schloß gesteckt wurde, war ich zu bange, aufzustehen und ihr Gesicht zu sehen. Ich hörte, wie sie ihr Zimmer aufschloß, drinnen leise trällernd hin und her ging, und später stand ich auf und wartete in der Diele. Sehr plötzlich war es still in ihrem Zimmer, sie ging nicht mehr hin und her, sang auch nicht mehr, und ich hatte Angst anzuklopfen. Ich hörte den langen Jugoslawen, der leise murmelnd in seinem Zimmer auf und ab ging, hörte das Brodeln des Wassers in der Küche meiner Wirtin. In Annas Zimmer aber blieb es still, und durch die offene Tür des meinen sah ich die schwarzen Flecke von den vielen ausgedrückten Zigaretten an der Tapete.

Der lange Jugoslawe hatte sich aufs Bett gelegt, ich hörte seine Schritte nicht mehr, hörte ihn nur noch murmeln, und der Wasserkessel in der Küche meiner Wirtin brodelte nicht mehr, und ich hörte das blecherne Rappeln, als die Wirtin den Deckel auf ihre Kaffeekanne schob. In Annas Zimmer war es immer noch still, und mir fiel ein, dass sie mir später alles erzählen würde, was sie gedacht hatte, als ich draußen vor der Tür stand, und sie erzählte mir später alles.

Ich starrte auf ein Bild, das neben dem Türrahmen hing: ein silbrig schimmernder See, aus dem eine Nixe mit nassem blondem Haar auftauchte, um einem Bauernjungen zuzulächeln, der zwischen sehr grünem Gebüsch verborgen stand. Ich konnte die linke Brust der Nixe halb sehen, und ihr Hals war sehr weiß und um ein wenig zu lang.

Ich weiß nicht wann, aber später legte ich meine Hand auf die Klinke, und noch bevor ich die Klinke herunterdrückte und die Tür langsam aufschob, wusste ich, dass ich Anna, gewonnen hatte: ihr Gesicht war ganz mit bläulich schimmernden kleinen Narben bedeckt, ein Geruch von Pilzen, die in der Pfanne schmorten, kam aus ihrem Zimmer, und ich schob die Tür ganz auf, legte meine Hand auf Annas Schulter und versuchte zu lächeln.

\section{Copyrights}

Copyright for this article is retained by the author(s), with first publication rights granted to the journal.

This is an open-access article distributed under the terms and conditions of the Creative Commons Attribution license (http://creativecommons.org/licenses/by/4.0/). 